\title{
Applying Kano Theory on Career Service in Library \& Learning Resources of University of Borås
}

\author{
Mingzi Li (Corresponding author) \\ School of Management, University of Shanghai for Science and Technology \\ Room 306, Building 4, No. 476 Changning Road, Changning District, Shanghai 200042, P.R. China \\ E-mail: limingzi007@gmail.com
}

Yan Jiang

School of Management, University of Shanghai for Science and Technology, P.R. China

E-mail: ppjyan@163.com

Shijie Hao

School of Engineering, University of Borås

Allégatan 1, Borås S-501 90, Sweden

The research is supported by Library \& Learning Resources of University of Borås.

\begin{abstract}
The purpose of this research is to evaluate the career service in Library\& Learning Resources of University of Borås (HB) and its communication channels with students based on the Kano theory in order to find which current services are basic needs, expected needs and attractive needs of students. Especially seeking potential attractive quality can make students know and experience the career service on their own initiative. From the analysis of Kano questionnaire, we could not only know students' different needs clearly but also find suggestions and recommendations of improvement for the future.
\end{abstract}

Keywords: Kano theory, Basic needs, Expected needs, Attractive needs, Attractive quality, Kano questionnaire

\section{Introduction}

\subsection{Research background}

Library and Learning Resources (LLR) of university of Borås is rank No.1 among all university libraries in Sweden. It is very famous for its quality management. LLR accepted the audits and quality inspections from the University of Borås, as quality of LLR is a part of the whole university's quality system. Through the interview with Catta Torhell who is the director for LLR, we get to know that LLR itself highly focuses on the quality management as well. Every August, they provide a new plan for next three years, and at the same time check how much they have done according to the older plans which were made by last three years. Through such continue forwards planning and go back checking, they get the continuous improvement. Every other year, they invite the consultants from professional consulting companies to develop a completed survey and other quality approaches to improve their performance.

In 2010, LLR will challenge several changes in order to improve its quality. Launching a new classification system called DDC (Dewey decimal classification) instead of SAB (a Swedish classification scheme) will begin in summer of 2010.Before new changes making, at the end of April, LLR invited consultants to help it improve their quality of service.

It is obvious that, LLR has completed quality management system and has good services to meet the students' basic needs. However, it still has the headache issues just as the old saying that" nothing can be perfect". After interviews with all the managers in different department, we found that many considerable services such as career services are unknown by the students, no mention that the students would like to come and join activities 
offered by the career service department. This study we mainly focus on the career service which is very important but easily ignored by students. We try to fulfill the big wish just as Director Catta said: "We had a picture of what we do, and students also have such kind of picture of what we should do. We want to exchange pictures with students, not only let students know and understand us, but also understand and learn students' pictures."

\subsection{Significance of the research}

Since the financial crisis of 2007-2009 is bringing some pressure to job markets all over the world, many graduates want to find a satisfied job after graduating as soon as possible. A university not only gives eligible graduates degrees, but also provides them career services before graduating even earlier. The career service can help students plan their career and get more effective choices in their programs. So we can see that is a necessary matter and can better meet many students' needs. But we know though the career service department provides services to students, it is unknown by some students. Through long-term studying, we find out Kano model is a model that can be better at understanding and predicting customers' needs and expectations (Klefsjö \& Bergman, 2003). Passing through research process, we found the reasons of weak information literacy services of the career service department. And then we combined Kano theory and the career service of universities in order to investigate students' actual requirements. It is convenient and effective to serve students and also can avoid the weak information literacy. The more students get the quality career services, the easier they can get satisfied jobs. At the same time, the university can gain more reputation which can attract more and more students to apply for studying there. It is a beneficial circulation.

\subsection{Brief introduction of Career service department}

This research is conducted by Library \&Learning Resources (LLR) of University of Borås with the purpose of improving the quality of their career services. Student career service office is just one of the student services in the student service department in LLR of University of Borås. Susanne is the only person who works with career services and has close relationship with the study consulting division. The career service focuses on the students who are studying in the last year at HB. It is mainly about guiding them to enter the job market. Their services include instructions on how to analyze the labor market, review of your CV and other job applications, training in how to present yourself, interview training and activities with the purpose to create contacts between the student and the labor market. In daily working, the career service office keep in touch with students through meeting, internet, open lectures, job fair, student union and words of mouth communication.

\section{Research Methods}

\subsection{Kano Questionnaire}

Kano Questionnaire is one of the simplest ways to get the customers' opinions. Based on three steps to develop and administer the Kano questionnaire described by Baek, Paik, \& Yoo (2009), the authors followed new three steps before Kano questionnaire design:

Step 1: Identify Service features

The first step to develop the Kano questionnaire is to identify service features that will be grouped into six Kano attributes. Based on career services currently provided, this study identifies 6 current services. And also identify the 3 potential services that students may be interested in.

\section{Step 2: Develop the Kano Questionnaire}

"The Kano questionnaire consists of pairs of customer requirement questions: how do you feel if a feature is presented (functional questions), and How to you feel if the same feature is not presented (dysfunctional questions)." (Baek, Paik, \& Yoo, 2009) Depending on customers' responses on two types of questions (functional/dysfunctional questions), we determine whether a specific service is an Exciter/Attractive feature, a linear feature, a must-be feature, an indifferent feature, or a reverse feature. See details in Table 1.

Step 3: Determine Service features

"Based on the responses to the functional and dysfunctional questions, each career service is classified into one of the six Kano categories." (Baek, Paik, \& Yoo, 2009) Figure 3 describes the relationship between Kano categories and six features.

\subsubsection{Kano questionnaire design}

In order to evaluate students' satisfaction on the career service in the Library \&Learning Resources of University of Borås, we designed a questionnaire based on Kano model which named "Survey of Career Service in Library 
\&Learning Resources in University of Borås" .This questionnaire includes twenty -one questions and is divided into two parts. From the first part of this questionnaire, there are fourteen questions based on Kano model about seven current services in the career service. For every service, we asked two questions that are the functional question "how do you feel if the career service department has such service?" and dysfunctional question "how do you feel if the career service department does not have such service?" Each of them, we made five options stand for the five quality attributes based on the Kano model: I expect it to be this way which means must be in the Kano questionnaire theory, I like it that way, I am neutral, I can live with it this way, and I dislike it this way. We try to find students' attitude to that service in order to find which kind of quality that the service belongs to. In the second part, there are several questions also based on Kano model. Hereinto, through brainstorming we listed some potential services needed by students. Finally for the sake of comprehensive consideration, we gave students an opportunity to express their own opinions on the career service. The aim of Part two is to find students' potential needs, in other words, which means attractive quality of the career service.

\subsubsection{Kano Questionnaire delivery and collection}

We made Kano Questionnaire by using internet software, so the answers of the questionnaire were automatically collected into our account when they were hand in on internet. We sent the link of questionnaire to all the students which are studying in HB. Before the close date of the questionnaire, we totally received 120 valid answers. The delivery and collection period began on May 5th, 2010 and ended on May 15th, 2010, which lasted 10 days.

\subsection{Information Interviews and Directional Interviews}

"Information interviews occur when someone asks for information about the services of the library, for specific or nonspecific reasons. Information interviews generally develop in such a way that the librarian does more talking than the person making the inquiry." (Jennerich \& Jennrich, 1997)

It has been argued (Jennerich \& Jennrich, 1997) that "directional interviews should be rather straightforward but can come in many varieties." The characteristic of these questions should be simplification and uncomplicated.

In the beginning of our research, we interviewed the person who is in charge of the career service. Before the interview, we brought forward some questions which were about our research and wrote them down on a paper. During the interview, we first asked them to introduce their work to us. This step is information interview. After getting basic information, we asked our questions according to previous preparation and their words during the information interview. This phase is directional interview. Then we can get all useful information about what we want.

\subsection{Validity and Reliability}

The survey put in practice very well and from it we can get useful information, but a problem needs to be noticed. The respondents are less than the students which we sent the questionnaire to. Considering the respondents from the first or second year of Bachelor or Master which are not going to graduate, they do not know the career service very clearly. Therefore, their answers will affect our result a little.

However, for interviews, we use information interview and directional interview. And the interviewer is the principal of the career service. She is professional with all the services. In addition, the respondents refer to students come from Sweden and other countries and involve students from all the grades and schools.

\section{Frame of reference}

\subsection{Kano model}

Kano model is a model which can be better at understanding and predicting customers' needs and expectations. Customer needs of a product/service can be divided into three groups: Basic needs, which would not be mentioned if asked but if are not fulfilled, the customers will be dissatisfied. Expected needs, they are in customers' consciousness and be mentioned if asked. Excitement needs, they are not in customers' consciousness and customers do not know what can be fulfilled. But if these needs can be satisfied, the organization can create added value to customers. In order to get these three needs, we should create corresponding quality. For satisfying basic needs, we achieve must-be quality and for satisfying expected needs, we create expected quality. We find attractive quality can satisfy excitements needs and often help us get loyal customers. (Klefsjö \& Bergman, 2003)We can see Kano model visually in Figure 1.

\subsection{Kano questionnaire theory}

In Kano questionnaire, product features are usually divided into six attributes to gather the customers' needs. The six attributes are Attractive quality attribute, Must be quality attribute, One-dimensional quality attribute, 
Indifferent attribute, Reverse quality attribute and Questionable quality attribute. (Hanoum, 2009)To make it easy understanding, and more fix to our research, we would like to divide the product (here we divided the service) features into Must-haves, Linear, Exciter, Reverse and Indifferent features.

We compare the different names of the features stated in Hanoum, et al. (2009) with concepts described by Artem (2006) and give the explanation of each item in Table 1.

For each feature or group of features, the Kano questionnaire has two questions: "The functional question 'How do you feel if this feature is presented?' and dysfunctional question 'How do you feel if this feature is NOT presented?"' according to Artem (2006). And each question has five possible options: 1) I expect it to be this way 2) I like it that way 3) I am neutral 4) I can live with it this way 5) I dislike it this way Artem (2006). Students need to choose one of above options for answers. Artem (2006) pointed that "Asking both functional and dysfunctional questions helps to go beyond the simple 'priorities'."For example if the potential user expects some feature (Feature is instead of some service provided by the career service department in this context) to be presented, but can live without the feature, it is not really a mandatory feature. In another word, that is a not mandatory service for students in this research.

For example, if a customer tells that he likes to get quick service, but it is neutral for not getting quick service, so the quick service is an Exciter feature of services in the bank.

\subsection{Kano questionnaire and Kano model}

As mentioned before, the Kano questionnaire can examine which feature or features the service has among six features based on Kano questionnaire theory. Hence, this paper will combine Kano model with Kano questionnaire to analysis what kind of quality the services can meet from the customers' perspectives.

In the authors' opinion, there are only three features close to the Kano questionnaire, the Exciter feature can meet the excitement needs of customers and contribute attractive quality. The Linear features can meet the expected needs of customers and was treated as expected quality. And Must-haves feature can meet the basic needs of customers and belongs to Must-be quality. All the features we marked in red abbreviation in Figure 3.

However, Kano model doesn't include the other three features: Reverse feature, Indifferent feature and Questionable feature. For the reverse feature, we need to delete it because that is the wrong feature can make your customer dissatisfied when you have such feature. If we have indifferent feature, we need not to care about such feature, this kind of feature cannot decide the quality of your products. Questionable feature shows some problems happened. You need to analysis it very carefully, because it may be caused by the potential products you have never thought before or the inconsistent answers in the questionnaire.

\section{Research Analyses}

\subsection{Kano questionnaire analyses for current services}

First, we calculated the percentage of options for each question. Secondly, we classified the 1-14 questions into seven groups based on the seven services of the career service and analyzed the results in groups based on the Kano questionnaire Matrix (Table 2). To get the answer we used the statistical method, we chose the option which has the largest value of percentage after calculation. For example, we took the No.1 and 2 questions as a group and see the results in Figure 4 and 5.

We found the largest percentage option is Neural (41\%) in the functional question No.1, by contrast the largest percentage option in dysfunctional question No.10 is also Neutral (45\%), according to the Matrix, we found the feature is "I" which means the individual conversation with career counselor is indifferent service to almost $45 \%$ students. However, $40 \%$ students still chose "I like it that way" option, which is just $1 \%$ less than the students who chose Neutral (41\%). In this analysis, the authors also valued this group of students' views, and found this service also has "E" feature which deducted by 40\% Neural answers in Functional Question No.1 and 45\% Neutral in dysfunctional Question No.2. As a result, almost half informants think "Individual conversations with career counselor" service is attractive as well as others think this service is indifferent. In a similar way, the results of analyzing other 6 services according to Table 2 are listed in Table 3.

In conclusion, Table 4 show which service has what kind of feature and belongs to what kind of quality.

Related to "Individual conversations with career counselor", we got two features as described at the beginning, one of the reasons behind this may be the personality of the students: some students do not like talking with others and they don't care so much about whether existing such service or not. Language problem may be another reason, international students who know little about Swedish or has communication problems in English may be afraid of face to face conversations with career counselor. However, this service still has attractive for large amount of 
students, so this service belongs to the attractive quality from a positive perspective.

"Review of your CV and other job applications" has both Exciter and Linear two features, which means this service is really expected by students and has a certain attractive to students. The authors also attribute it to the attractive quality in this research.

Generally speaking, this analysis shows nearly the seven services that the career service offered by now fit the students' expectation and has a certain attractive feature. Only "Instruction on how to analyze the labor market" seems not so necessary from students' views based on the result of the questionnaire.

\subsection{Kano questionnaire analysis for potential service}

The potential service was assumed to be able to help build attractive quality and examined whether belongs to the attractive quality by the second part of the questionnaire (Question No.15 to Question No.20). This part of analysis will use the same logic of analysis as above. Table 5 is the result of analyzing three potential services.

The result shows that "professional test with purpose of analyzing yourself" and "offer some information of companies' job vacancies on the website" belongs to the attractive quality with the features Exciter and Linear. This indicates students want to know themselves in a professional way, and want the career service offer final useful information like job vacancies on the website. One of the reasons behind that may be most students are always too busy or lazy to search such information by themselves, they expect more directly and completed free service. Another possible reason because many students are international ones who have difficulty to search Swedish job market information by themselves because their incomprehension of the Swedish market.

The opportunity to "vote for the subjects of open lecture" does not attract students' attention so much. This result shows the students are more focused on the practical information and have a rational mind.

From the result of open Question 21, we collected students' expectations on the career service. In it, one respondent put forward a problem of job fair service. There are two job fairs every year, the big one is always in spring every year, mainly for economic students, and another is multi display for the company. In textile school, they have company day, so that the company can come and offer students the job and thesis opportunity. In that day, most companies just ask students to upload their webpage but not give some useful tips about finding job. So some students went to the job fair but found nothing helpful, then they will do not experience this service again because they think it is losing time and useless.

\section{Recommendation}

\subsection{Customer focus in the whole student education process}

Customer focus is one of Quality Management Principles of ISO 9000:2000. Klefsjö \& Bergman(2003) argue that "organizations depend on their customers and therefore should understand current and future customer needs, should meet customer requirements and strive to exceed customer expectation."

According to the interview of Susanne, we know that there is a student education process in University of Borås. It is divided into three parts: application period, study period and planning career period. The career service focus on the third part and the study counselors focus on foregoing phases. We propose that the career education should go through the whole student education process. In the study period, the career service can cooperate with study counselors to help students to know themselves better through professional test and know the job market as early as possible. In this way, the career service can get more information about the needs of their potential customers.

\subsection{Building smoothly communication with students}

\subsubsection{Adopting new communication methods to improve the efficiency of communication}

According to the interview of Susanne, we find that though students can be provided good services by their department, some of them never experience the career service even heard of. It is shown that the communication between the career service department and students is not so good. Through the analysis of the survey, we can see most students need the career service.

Poster (1990) argues that electronic communications are new language experiences in part by virtue of electrification. And the benefits of electronic channels are low cost, customer convenience, wide distribution and quick customer feedback. (Zeithaml, Bitner, \& Gremler, 2009)So in order to improve the efficiency of communication channels, we suggest using video instead of information written on the paper. The career service can be made into a video which can be played in the entrance of the library. It is easy to attract students to see it and then know the career service further. 


\subsubsection{Reinforce the words of mouth communication}

Littlejohn (1992) argues that "communication is one of our most pervasive, important, and complex clusters of behaviors. Our daily lives are strongly affected by our own communication with others as well as by messages from distant and unknown persons." And it has been argued(Zeithaml, Bitner, \& Gremler, 2009)that "services consumers are strongly influenced by the personal opinions of others, understanding and controlling word-of-mouth communication becomes even more important for service companies."

According to the interview of Susanne, we see that a number of students heard of the career service from other students. And it can show that words of mouth communication is important for the career service to inform information to students. So if the career service department can cooperate with student union and ask their influential students to introduce the career service to students, more and more students would know the career service further.

\subsubsection{Make the webpage customer- friendly and easy to access}

Firstly, nowadays customers are subjected to many service choices. Companies should research customer behavior in a services context. That means before making sure which or where services provide to customers, it is necessary to study customer behavior. (Lovelock, Wirtz, \& Chew, 2009) Considering students always log in to some social websites, so the career service department can use the social internet communication channels like Facebook, YouTube and Twitter to inform students. It is more customer- friendly.

Secondly, according to the interview with Susanne, we know that the career service has a vivid Swedish webpage which includes the links of Facebook, YouTube and so on. And this link of the career service is set up on the homepage of university of Borås. That is convenient and easy to access. But the English webpage of the career service need three or four steps to access so the click rate is lower than the Swedish one. And we also know that so many students never access the English webpage of the career service.

Therefore, it is important for the career service to pay more attention to the design of its English webpage in order to satisfy and attract students who cannot speak Swedish. Moreover, the English webpage should be reset up to be accessed easily. Maybe it can be designed with Swedish webpage together which is on the homepage.

\subsection{Improve the attractive quality}

Hoyle (2009) suggests that the first step of the four steps of effective communication is attention. Actually, the Exciter feature can easily cause the customers' attention and improve the effectiveness of communication. Based on the result of Kano questionnaire, most services that the career service had offered to students has the Exciter which can contribute to Attractive quality. The result means even if you serve students in a lower level of quality, you still hardly get the dissatisfaction. The reason is quite clear as (Jeongyun, Sanhyun, \& Chiwon, 2007) described that attractive quality has the contrary meaning of the basic quality. Though the absence of attractive quality does not promote the user's dissatisfaction, if the career service provides services of these features, it could excite and delight users. In other words, students are easily attracted by the services or products which have the "WOW "feature and probably would like to know more and experience such kind of service. Attractive quality is always characterized by the Exciter feature which can also be called WOW feature in student perspective. Therefore, we need to focus on the attractive quality of career service.

Career Service need to continually provide interview training services and training students how to present themselves. Review of your CV and other job applications and individual conversations with career counselor should be provided in a professional way. In the individual conversation meeting, the authors recommend using the professional test which is already inspected that it has attractive quality's feature by Kano Questionnaire. Providing the professional tests on the webpage or by e-mail delivered to students regularly is another solution to attract the students' attention and invite them come to the service soundlessly.

Provide more open lectures in different interesting subjects, and invite quality person such as HR in Recruiting Company to join the lectures. The language choice is so important that can influence the participation number of students. By now the focused job market is mainly in Sweden, the availability of English for some lectures is quite a key issue to attract more international students' participation. In the introduction lecture at the beginning of every academic year, some students who had successful experience of studying and working in Sweden can also are invited as the speaker to set new students a good example.

Offer some information about job vacancies in companies on the school webpage. It is not only perfect the career service to achieve the students' satisfaction, but also a good opportunity to market students who are studying in University of Borås. Through communication with the companies the "Win-Win" state for both university and companies will be expected. 


\section{Conclusion}

During this research we applied Kano theory on the career service in Library \& Learning Resources of University of Borås. After the analysis of Kano questionnaire, we found out the career service department did the good job and most services could belong to attractive quality which can add value to the students. However, in some aspects, the career service should be improved. So we gave some recommendation to the career service according to their bottle-necks for a while in the past in order to build and improve their attractive quality better.

We know anyone who stops improving soon stops being good. (Klefsjö \& Bergman, 2003)The career serivce also need improvement. It should follow PDSA circle to investigate students' needs every several month based on Kano questionnaire and improve their services in time.

Kano theory can be a good way to better know and classify the needs of customers. In this research we took the career service in Library \& Learning Resources of University of Borås as an example. But it can be used in every walk of life.

\section{References}

(2006). Kano questionnaires [WWW

page].

[Online]

Available: http://agilesoftwaredevelopment.com/2006/12/kano-questionnaires.

Baek, S. I., Paik, S. K., \& Yoo, W. S. (2009). Understanding Key Attributes in Mobile Service: Kano Model Approach. Computer Science, 5618,357-358.

Hanoum,et al. (2009, 11 4-5). Prioritizing Healthcare Service Attributes: Comparing Importance Performance Analysis and KANO's Model. Paper presented at the Proceedings of 2 nd Asia Pacific Conference on Manufacturing System, Yogyakarta. Indonesia: Sepuluh Nopember Institut Technology (ITS) Surabaya.

Hoyle, D. (2009). ISO 9000 Quality Systems Handbook (6th ed.). Oxford: Elservier Ltd.

Jennerich, E. Z., \& Jennrich, E. J. (1997). The Referecnce Interview as a Creative Art (2nd ed.). Colorade: Libraries Unlimited Inc.

Jeongyun, H., Sanhyun, P., \& Chiwon, S. (2007). A Study on the improving Product Usability Applying the Kano's Model of Customer Satisfaction. Computer Science, 4550,483-485.

Klefsjö, B., \& Bergman, B. (2003). Quality from Customer Needs to Customer Satisfaction (2nd ed.). Lund: Studentlitteratur.

Littlejohn, S.W. (1992). Theories of Human Communication (4th ed.). Belmont: Wadsworth.

Lovelock, C., Wirtz, J., \& Chew, P. (2009). Essentials of Services Marketing (1st ed.). Jurong: Prentice Hall.

Poster, M. (1990). THE MODE OF INFORMATION (1st ed.). Oxford: Blackwell Publishers.

Zeithaml, V. A., Bitner, M. J., \& Gremler, D. D. (2009). Services Marketing intergrating customers focus across the firm (5th ed.). New York: McGraw-Hill Companies.

Table 1. Concepts of six features' name comparison (Hanoum, 2009 \& Artem, 2006)

\begin{tabular}{l|l|l}
\hline \multicolumn{1}{c|}{ Six features' name } & \multicolumn{1}{|c}{ Original name } & \multicolumn{1}{c}{ Meaning } \\
\hline Must-haves feature & $\begin{array}{l}\text { Must be quality } \\
\text { attribute. }\end{array}$ & $\begin{array}{l}\text { When current these attributes can be fulfilled, } \\
\text { customers will be satisfied. If not, customers } \\
\text { will be dissatisfied. }\end{array}$ \\
\hline Linear feature & $\begin{array}{l}\text { One-dimensional } \\
\text { quality attribute }\end{array}$ & $\begin{array}{l}\text { The customer satisfaction level is directly } \\
\text { proportional to the certain quality attribute. }\end{array}$ \\
\hline Exciter feature & $\begin{array}{l}\text { Attractive quality } \\
\text { attribute }\end{array}$ & $\begin{array}{l}\text { A certain quality attribute can originate great } \\
\text { satisfaction in the customer. However, if the } \\
\text { same quality attribute is not present, that will } \\
\text { not originate dissatisfaction. }\end{array}$ \\
\hline Reverse feature & $\begin{array}{l}\text { Reverse quality } \\
\text { attributes }\end{array}$ & $\begin{array}{l}\text { When current these attributes cannot be } \\
\text { fulfilled, customers will be satisfied. If not, } \\
\text { customers will be dissatisfied. }\end{array}$ \\
\hline Indifferent feature & $\begin{array}{l}\text { Indifferent quality } \\
\text { attribute }\end{array}$ & $\begin{array}{l}\text { The presence or absence of these quality } \\
\text { attributes will not affect attitudes of customers. }\end{array}$ \\
\hline Questionable feature & $\begin{array}{l}\text { Questionable quality } \\
\text { attributes }\end{array}$ & $\begin{array}{l}\text { The customer may give ambivalent responses } \\
\text { due to misunderstanding of the answers on the } \\
\text { survey or filling out the error questionnaires. }\end{array}$ \\
\hline
\end{tabular}


Table 2. Illustrates how six features come from Kano Questionnaires (Artem, 2006)

\begin{tabular}{c|c|c|c|c|c|c}
\hline & & \multicolumn{5}{|c}{ Dysfunctional question } \\
\hline \multirow{5}{*}{ Functional question } & options & Like & Expect & Neutral & Live with & Dislike \\
\cline { 2 - 8 } & Like & Q & E & E & E & L \\
\cline { 2 - 8 } & Expect & R & I & I & I & M \\
\cline { 2 - 8 } & Live with & R & I & I & I & M \\
\cline { 2 - 8 } & Dislike & R & R & R & R & Q \\
\hline
\end{tabular}

M - Must have

$\mathrm{L}-$ Linear

E - Exciter

$\mathrm{R}$ - Reverse, i.e. wrong features that would make the user experience worse

$\mathrm{Q}$ - Questionable, i.e. the potential user answers are inconsistent

I - Indifferent, i.e. the potential user doesn't really care about the feature

Table 3. Current result analysis based on Kano Questionnaire

\begin{tabular}{|c|c|c|c|c|c|c|c|}
\hline 7 current services & Q no. & LOF & LO DF & M F & Close LOF & Close LO DF & $\mathrm{CF}$ \\
\hline $\begin{array}{l}\text { Individual } \\
\text { conversations with } \\
\text { career counselor }\end{array}$ & $9 / 10$ & $\mathrm{~N}(41 \%)$ & $\mathrm{N}(45 \%)$ & I & $\mathrm{L}(40 \%)$ & $\mathrm{N}(45 \%)$ & $\mathrm{E}$ \\
\hline $\begin{array}{l}\text { Instructions on how } \\
\text { to analyze the labor } \\
\text { market }\end{array}$ & $11 / 12$ & $\mathrm{~N}(50 \%)$ & $N(53 \%)$ & $\mathrm{I}$ & & & \\
\hline $\begin{array}{l}\text { Review of your CV } \\
\text { and other job } \\
\text { applications }\end{array}$ & $13 / 14$ & $\mathrm{~L}(44 \%)$ & $\mathrm{D}(35 \%)$ & $\mathrm{L}$ & $\mathrm{L}(44 \%)$ & $\mathrm{N}(34 \%)$ & $\mathrm{E}$ \\
\hline $\begin{array}{l}\text { Training in how to } \\
\text { present yourself }\end{array}$ & $15 / 16$ & $\mathrm{~L}(46 \%)$ & $\mathrm{N}(40 \%)$ & $\mathrm{E}$ & & & \\
\hline Interview training & $17 / 18$ & $\mathrm{~L}(47 \%)$ & $\mathrm{N}(39 \%)$ & $E$ & & & \\
\hline $\begin{array}{l}\text { job fair with the } \\
\text { purpose to create } \\
\text { contacts between } \\
\text { the student and the } \\
\text { labor market }\end{array}$ & $19 / 20$ & $\mathrm{~L}(41 \%)$ & $\mathrm{D}(41 \%)$ & $\mathrm{L}$ & & & \\
\hline $\begin{array}{l}\text { open lecture with } \\
\text { the purpose to } \\
\text { create contacts } \\
\text { between the student } \\
\text { and the labor } \\
\text { market }\end{array}$ & $21 / 22$ & L (49\%) & $\mathrm{N}(46 \%)$ & $\mathrm{E}$ & & & \\
\hline
\end{tabular}

Q no.-question number in the questionnaire

$\mathrm{L} \mathrm{O} \mathrm{F}$ - the largest option with its value in the functional question

LO DF - the largest option with its value in the dysfunctional question

M F - the feature which this service belongs to based on LO F and Most LO DF according to Matrix (Table 2)

Close LOF - the option which value is the same as or only $1 \%$ close to the value of LOF in the functional question

Close LODF - the option which value is the same as or only $1 \%$ close to the value of LO DF in the dysfunctional question

C F - the feature which this service belongs to based on Close LOF and Close LO DF according to Matrix (Table 2) 
Table 4. Identify the type of quality according to feature of services

\begin{tabular}{l|l|l}
\hline \multicolumn{1}{c|}{ Quality } & \multicolumn{1}{c}{ Feature } & \multicolumn{1}{c}{ Services } \\
\hline Attractive Quality & Exciter/Indifferent & Individual conversations with career counselor \\
\hline Attractive Quality & Exciter/Linear & Review of your CV and other job applications \\
\hline Attractive Quality & Exciter & Training in how to present yourself \\
\hline Attractive Quality & Exciter & Interview training \\
\hline Attractive Quality & Exciter & $\begin{array}{l}\text { open lecture with the purpose to create contacts } \\
\text { between the student and the labor market }\end{array}$ \\
\hline Exceptive Quality & Linear & $\begin{array}{l}\text { job fair with the purpose to create contacts } \\
\text { between the student and the labor market }\end{array}$ \\
\hline No concern Quality & Indifferent & Instructions on how to analyze the labor market \\
\hline
\end{tabular}

Table 5. Potential service result analysis based on Kano Questionnaire

\begin{tabular}{l|c|c|c|c|c|c|c}
\hline \multicolumn{1}{c|}{3 potential services } & Q no. & LOF & LO DF & M F & Close LOF & Close LODF & C F \\
\hline $\begin{array}{l}\text { professional test with purpose } \\
\text { of analyzing yourself }\end{array}$ & $25 / 26$ & $\mathrm{~L}(44 \%)$ & $\mathrm{N}(51 \%)$ & $\mathrm{E}$ & & & \\
\hline $\begin{array}{l}\text { opportunity to vote the } \\
\text { subjects of open lecture }\end{array}$ & $27 / 28$ & $\mathrm{~N}(45 \%)$ & $\mathrm{N}(56 \%)$ & $\mathrm{I}$ & & & \\
\hline $\begin{array}{l}\text { offer some information of } \\
\text { companies' job vacancies on } \\
\text { the website }\end{array}$ & $29 / 30$ & $\mathrm{~L}(48 \%)$ & $\mathrm{N}(35 \%)$ & $\mathrm{E}$ & $\mathrm{L}(48 \%)$ & $\mathrm{D}(35 \%)$ & $\mathrm{L}$ \\
\hline
\end{tabular}

Q no.- question number in the questionnaire

L O F - the largest option with its value in the functional question

LO DF - the largest option with its value in the dysfunctional question

M F - the feature which this service belongs to based on LO F and Most LO DF according to Matrix (Table 2)

Close LOF - the option which value is the same as or only $1 \%$ close to the value of LOF in the functional question

Close LODF - the option which value is the same as or only $1 \%$ close to the value of LO DF in the dysfunctional question

$\mathrm{C} \mathrm{F}$ - the feature which this service belongs to based on Close LOF and Close LO DF according to Matrix (Table 2)

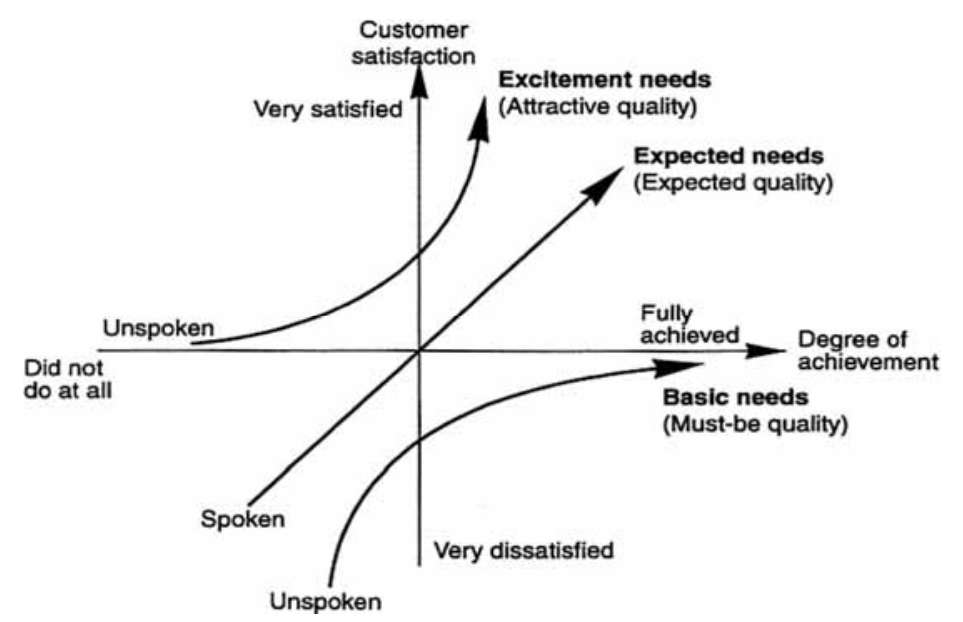

Figure 1. Kano model for customer satisfaction (Klefsjö \& Bergman, 2003) 


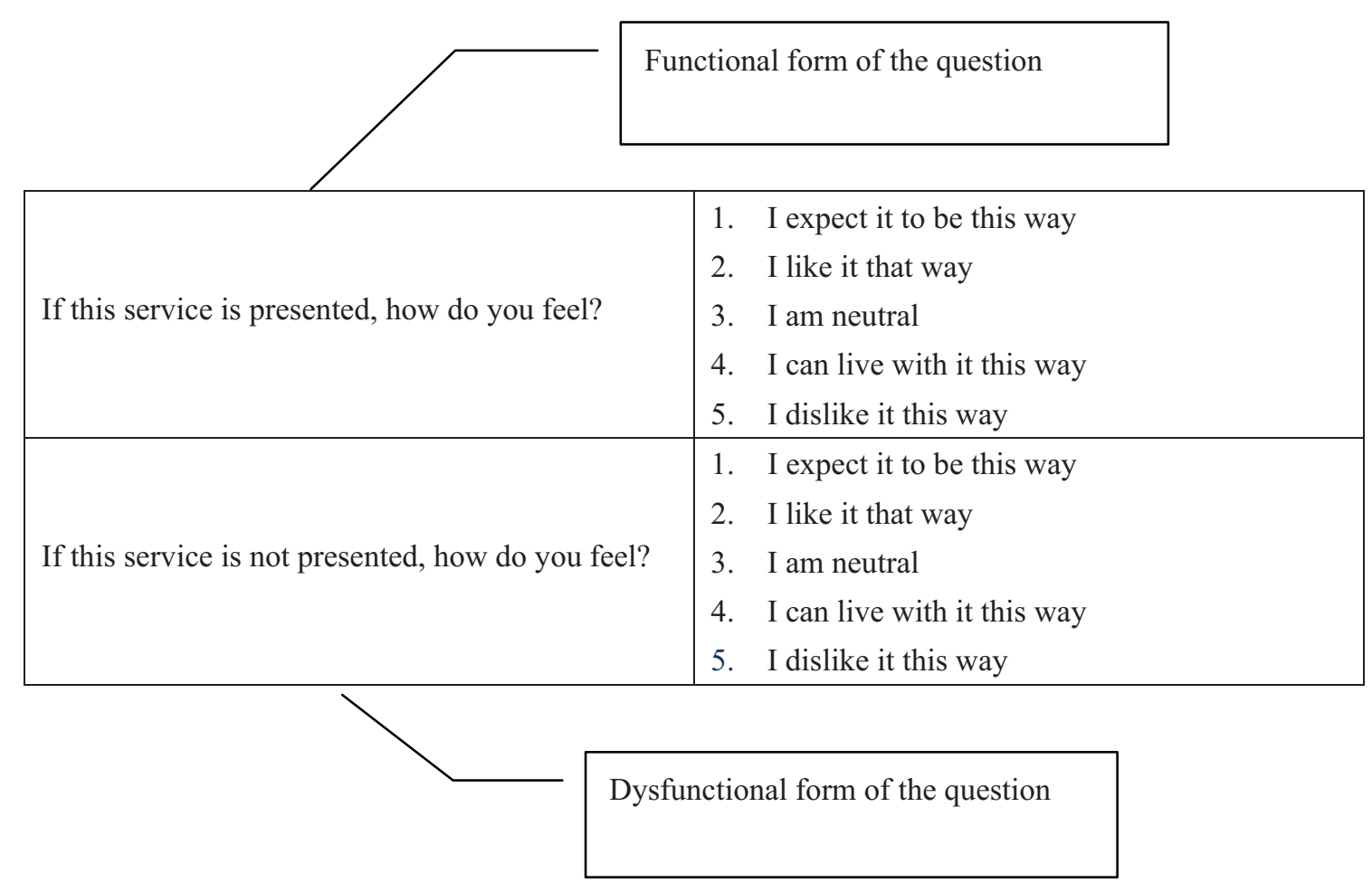

Figure 2. A pair of requirement questions in a Kano questionnaire (Jeongyun, Sanhyun, \& Chiwon, 2007)

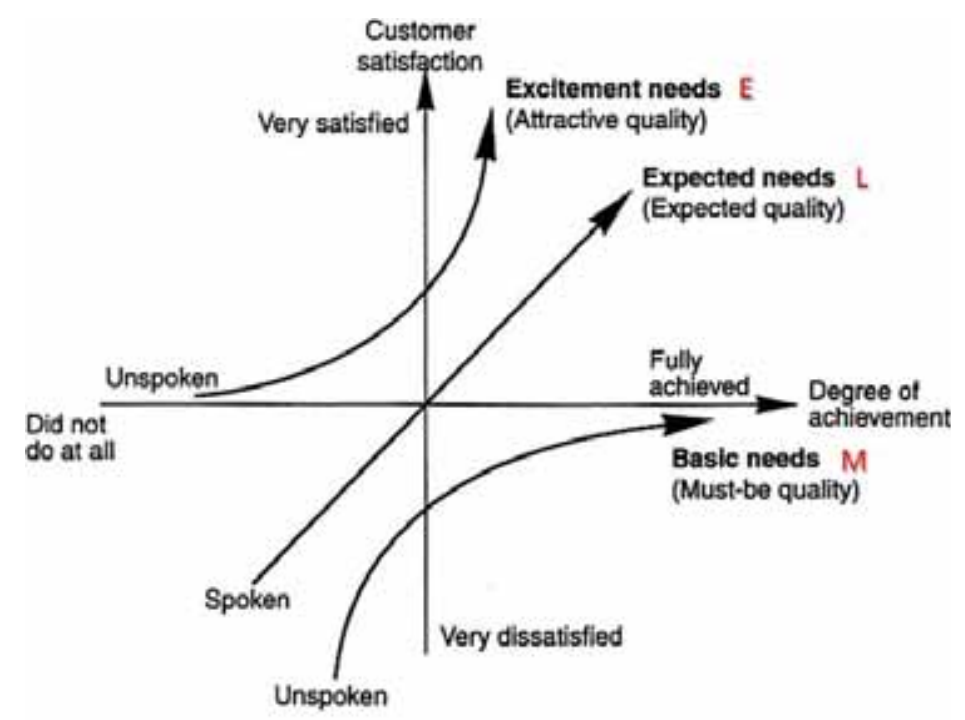

Figure 3. Kano Model with three features concluded from Kano Questionnaire. Resource: based on (Klefsjö \& Bergman, 2003) 


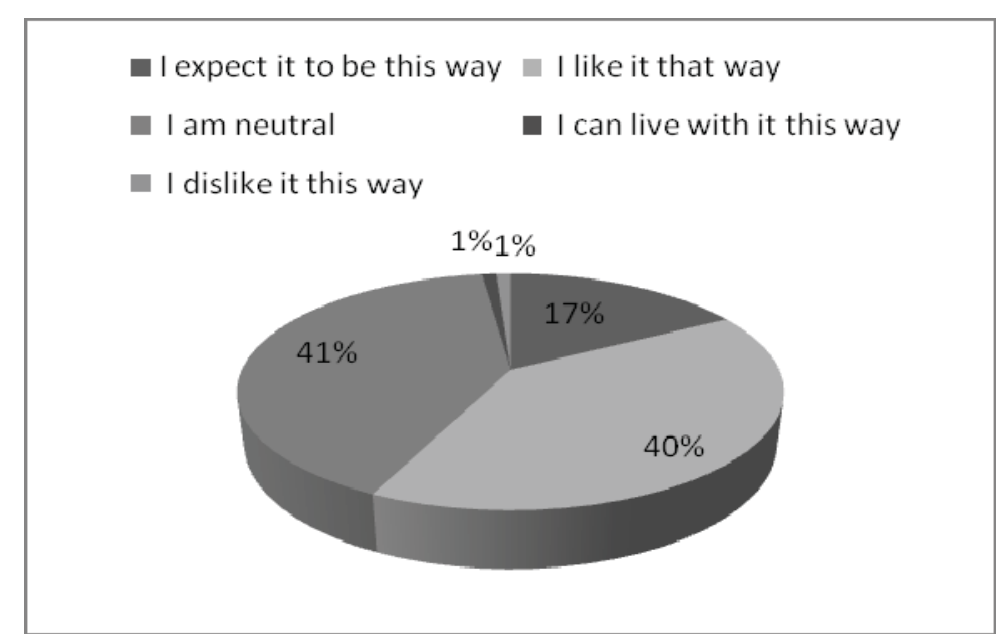

Figure 4. Result of Question No.1

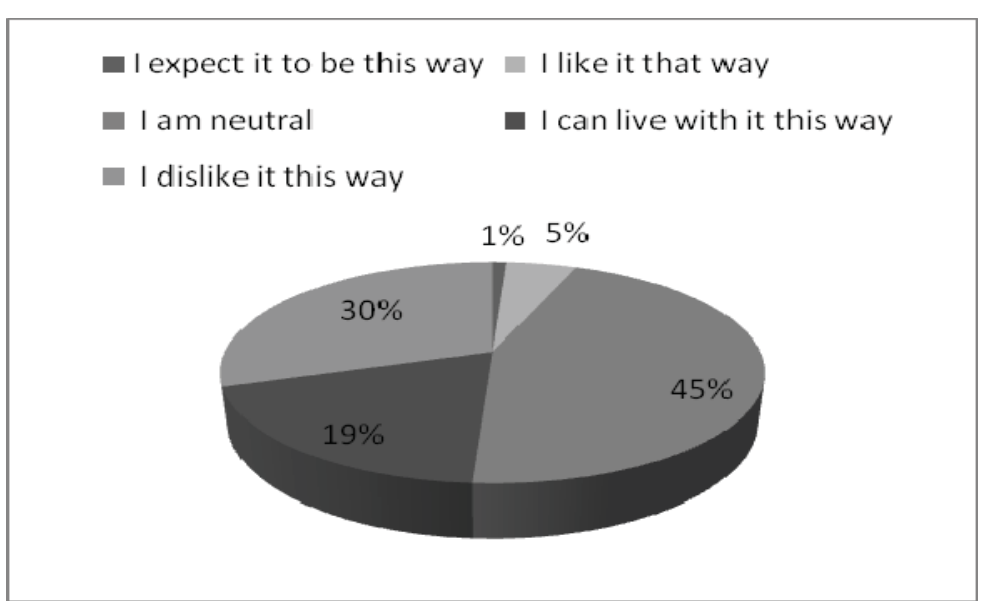

Figure 5. Result of Question No.2

\section{Appendix}

Survey of Career Service in Library \& Learning Resources in University of Borås

This questionnaire is concerning the student' attitudes about the career service in Library \& Learning Resources in University of Borås.

This questionnaire with 21 questions will be sent to students who are studying in University of Borås. And we would be grateful if you could answer the following questions honestly. Your answers will be treated in confidence and kept anonymous.

Note: The questionnaire is not the original format but the same contents.

1. How do you feel if career service has "Individual conversations with career service counselor" service?

$\circ$ I expect it to be this way

$\circ$ I like it that way

○ I am neutral

$\circ$ I can live with it this way

$\circ$ I dislike it this way

2. How do you feel if career service does not have "Individual conversations with career service counselor" service?

$\circ$ I expect it to be this way

$\circ$ I like it that way

$\circ$ I am neutral

$\circ$ I can live with it this way

$\circ$ I dislike it this way

3. How do you feel if career service has "Instructions on how to analyze the labor market" service? 
O I expect it to be this way

o I like it that way

o I am neutral

$\circ$ I can live with it this way

$\circ$ I dislike it this way

4. How do you feel if career service does not have "Instructions on how to analyze the labor market" service?

$\circ$ I expect it to be this way

o I like it that way

o I am neutral

$\circ$ I can live with it this way

○ I dislike it this way

5. How do you feel if career service has "Review of your CV and other job applications" service?

o I expect it to be this way

○ I like it that way

- I am neutral

$\circ$ I can live with it this way

O I dislike it this way

6. How do you feel if career service does not have "Review of your CV and other job applications" service?

o I expect it to be this way

$\circ$ I like it that way

o I am neutral

O I can live with it this way

- I dislike it this way

7. How do you feel if career service has "Training in how to present yourself" service?

o I expect it to be this way

o I like it that way

- I am neutral

$\circ$ I can live with it this way

o I dislike it this way

8. How do you feel if career service does not have "Training in how to present yourself" service?

$\circ$ I expect it to be this way

o l like it that way

- I am neutral

$\circ$ I can live with it this way

○ I dislike it this way

9. How do you feel if career service has "Interview training" service?

○ I expect it to be this way

o like it that way

o I am neutral

O I can live with it this way

o I dislike it this way

10. How do you feel if career service does not have "Interview training" service?

- I expect it to be this way

$\circ$ I like it that way

o I am neutral

O I can live with it this way

o I dislike it this way

11. How do you feel if career service has "job fair with the purpose to create contacts between the student and the labor market"?

$\circ$ I expect it to be this way

o I like it that way

o I am neutral

O I can live with it this way

O I dislike it this way

12. How do you feel if career service does not have "job fair with the purpose to create contacts between the student and the labor market"? 
O I expect it to be this way

$\circ$ I like it that way

o I am neutral

I can live with it this way

o I dislike it this way

13. How do you feel if career service has "open lecture with the purpose to create contacts between the student and the labor market"?

$\circ$ I expect it to be this way

$\circ$ I like it that way

$\circ$ I am neutral

$\circ$ I can live with it this way

$\circ$ I dislike it this way

14. How do you feel if career service does not have "open lecture with the purpose to create contacts between the student and the labor market"?

$\circ$ I expect it to be this way

$\circ$ I like it that way

- I am neutral

- I can live with it this way

$\circ$ I dislike it this way

15. How do you feel if career service offers "professional test with purpose of analyzing yourself"?

$\circ$ I expect it to be this way

o I like it that way

○ I am neutral

I can live with it this way

$\circ$ I dislike it this way

16. How do you feel if career service does not offer "professional test with purpose of analyzing yourself'?

$\circ$ I expect it to be this way

$\circ$ I like it that way

○ I am neutral

○ I can live with it this way

$\circ$ I dislike it this way

17. How do you feel if career service offers you an opportunity to vote the subjects of open lecture?

$\circ$ I expect it to be this way

$\circ$ I like it that way

- I am neutral

○ I can live with it this way

$\circ$ I dislike it this way

18. How do you feel if career service does not offer you an opportunity to vote the subjects of open lecture?

$\circ$ I expect it to be this way

$\circ$ I like it that way

o I am neutral

$\circ$ I can live with it this way

$\circ$ I dislike it this way

19. How do you feel if career service offers some information of companies' job vacancies on the webpage?

$\circ$ I expect it to be this way

$\circ$ I like it that way

○ I am neutral

$\circ$ I can live with it this way

$\circ$ I dislike it this way

20. How do you feel if career service does not offer some information of companies' job vacancies on the webpage?

$\circ$ I expect it to be this way

$\circ$ I like it that way

$\circ$ I am neutral

○ I can live with it this way

I dislike it this way

21. What is your expectation of career service? 